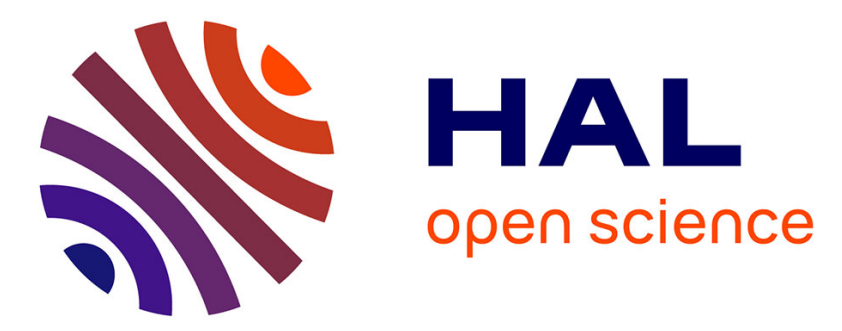

\title{
Determination of paramagnetic concentrations inside a diamagnetic matrix using solid-state NMR
}

Sébastien Maron, Nadège Ollier, Thierry Gacoin, Géraldine Dantelle

\section{To cite this version:}

Sébastien Maron, Nadège Ollier, Thierry Gacoin, Géraldine Dantelle. Determination of paramagnetic concentrations inside a diamagnetic matrix using solid-state NMR. Physical Chemistry Chemical Physics, 2017, 19 (19), pp.12175-12184. 10.1039/c7cp00451f . hal-03054309

\author{
HAL Id: hal-03054309 \\ https://hal.science/hal-03054309
}

Submitted on 11 Dec 2020

HAL is a multi-disciplinary open access archive for the deposit and dissemination of scientific research documents, whether they are published or not. The documents may come from teaching and research institutions in France or abroad, or from public or private research centers.
L'archive ouverte pluridisciplinaire HAL, est destinée au dépôt et à la diffusion de documents scientifiques de niveau recherche, publiés ou non, émanant des établissements d'enseignement et de recherche français ou étrangers, des laboratoires publics ou privés. 


\title{
Determination of a paramagnetic concentration inside a diamagnetic matrix by Solid-State NMR
}

\author{
Sébastien Maron ${ }^{\&, *}$, Nadège Ollier ${ }^{\ddagger}$, Thierry Gacoin ${ }^{\&}$, Géraldine Dantelle ${ }^{\dagger}$ \\ \&Laboratoire de Physique de la Matière Condensée, École polytechnique, \\ CNRS, Université Paris Saclay, 91128 Palaiseau Cedex, France \\ ${ }^{\ddagger}$ Laboratoire des Solides Irradiés, École polytechnique, CNRS, CEA, 91128 Palaiseau Cedex, \\ France \\ †Institut Néel CNRS, UPR 2940/Université Grenoble Alpes \\ 25 Av. des Martyrs - 38042 Grenoble Cedex 09, France \\ *sebastien.maron@polytechnique.edu
}

\begin{abstract}
The determination of very low doping levels in solid materials is an important issue for many applications. When considering paramagnetic dopants, NMR relaxation technique appears to be much more accurate than classical techniques such as the Vegard's law resulting from X-ray diffraction (XRD) measurement or chemical analysis that cannot provide information of appropriate dopant spatial distribution. In a recent report, the linear variation of $1 / T_{1}$, i.e. the nuclear relaxation rate, as a function of $\mathrm{Nd}^{3+}$ content has been used to determine doping levels with a good dispersion homogeneity in the monazite $\mathrm{LaPO}_{4}$ matrix down to 0.1 mol. \% . We here extend this study to more complex compounds doped with $\mathrm{Nd}^{3+}$, such as $\mathrm{YPO}_{4}$, the solid solution $\mathrm{Y}_{0.8} \mathrm{Sc}_{0.2} \mathrm{PO}_{4}, \mathrm{Ba} 5\left(\mathrm{PO}_{4}\right)_{3} \mathrm{Cl}$ and a phosphate glass. For all considered compounds except $\mathrm{Ba} 5\left(\mathrm{PO}_{4}\right)_{3} \mathrm{Cl}: \mathrm{Nd}, 1 / T_{1}$ is found to be linearly proportional to the nominal $\mathrm{Nd}$ concentration, confirming the ability of the method to investigate dopant concentration and spatial homogeneity. The results on different compounds open the discussion on the parameters influencing the nuclear relaxation rate, among which the orbital overlap and the average P-P distances.
\end{abstract}




\section{Introduction}

In many cases, the interesting physical properties of inorganic compounds are not intrinsic to the materials themselves but result from the addition of extra ions, called doping ions, allowing to control electrical, optical or magnetic properties. Trivalent rare-earth (RE) ions are widely used as doping ions in order to elaborate optically-active materials with various technological applications (lasing ${ }^{1}$, data memory ${ }^{2}$, phosphors etc...). These interesting optical properties are conferred by the $4 \mathrm{f}$ orbitals of RE, presenting the particularity to be shielded from the environment by the outer $5 \mathrm{~s}$ and $5 \mathrm{p}$ orbitals. In term of material synthesis, a key challenge is to obtain well-dispersed RE ions within their host matrix. Indeed, the formation of RE pairs, small aggregates or clusters usually decreases optical performances through RE-RE interactions. In optics, a well-known phenomenon is the concentration quenching for which, above a given RE concentration, the RE luminescence decreases as energy transfers between RE ions are likely to favor the RE de-excitation in a non-radiative manner (through defects, surface traps, etc), at the expense of the radiative de-excitation. ${ }^{3,4}$ In this context and for the mentioned applications, the doping concentration remains low, usually below 10 mol. \%., 6

Between the nominal and the real effective RE doping concentration, there can be a nonnegligible discrepancy due to dopant segregation during the synthesis (often observed in singlecrystals grown by Czochralski method ${ }^{7}$ ) or poor incorporation due to size or charge mismatch between the RE and the substituted ion. ${ }^{8}$ Heterogeneity of the RE distribution in the matrix can also result from unappropriate synthesis conditions, especially in the case of a bad mixing of the precursors or too low calcination temperatures (observed in ceramics prepared by solidstate reaction) or of a non-homogeneous melt in the case of glasses. It is thus very important to analyze the obtained compound in order to determine with accuracy its doping concentration and the good dispersion of the elements.

There are not many techniques to evaluate exactly a doping concentration, especially if this concentration is of the order of a few mol.\%. The commonly-used method is based on the position of Bragg diffraction peaks. Indeed, according to Vegard's law, the homogeneous incorporation of doping ions inside a matrix, corresponding the formation of a solid solution induces a shift of the X-ray diffraction peaks with respect to pure phases. This shift varies linearly with the concentration of substituting elements. The limitation of Vegard's law lies in the fact that the shift of the diffraction peaks is only visible when the insertion of the substituent is of a few mol.\%. ${ }^{9}$ In addition, this technique is only available for crystalline materials as it is based on the position of Bragg diffraction peaks. The crystallinity is also a restrictive factor for 
the use of the Electron Spin Resonance (ESR) for doping concentration determination. Indeed, ESR can be used to quantify the number of paramagnetic doping ions through the double integration of the ESR signal, but only if the samples are single-crystals. ${ }^{10,11}$ For other types of samples (amorphous or polycrystalline), the broadening of the ESR signal hides some characteristic features, such as ion pair signatures, and prevent any accurate quantitative measurements. ${ }^{12}$ Other techniques, such as Energy Dispersive X-ray analysis or Atomic Absorption spectrometry, turn out to be inappropriate for the detection of elements present at low concentration (typically below $1 \mathrm{~mol} . \%$ ) and are inadequate to provide information on element spatial dispersions. Finally, for optically-active materials, optical absorption spectroscopy can be used; but, for the absolute measurement of the doping concentration, the knowledge of the absorption cross-section is mandatory. ${ }^{7}$ Some other techniques could be used for determining very low doping concentrations (from 100's of ppm to sub-ppm) such as SIMS, electron microbeam with WDX and nanoSIMS but with a spatial resolution of 10 to $1 \mu \mathrm{m}$.

In this context, we focus on an original method based on Solid-State Nuclear Magnetic Resonance (SSNMR) relaxation to determine the doping concentration in some solid state materials, whether they are crystalline or amorphous. In a previous paper, we studied the $\mathrm{LaPO}_{4}$ crystalline compound doped by two different RE ions, $\mathrm{Gd}^{3+}$ and $\mathrm{Nd}^{3+}$, and measured their ${ }^{31} \mathrm{P}$ NMR relaxation time $T_{1}$ in static and MAS conditions. ${ }^{13}$ The key result of this study is the linear variation of $1 / T_{1}$ as a function of $\mathrm{Nd}^{3+}\left(\right.$ or $\mathrm{Gd}^{3+}$ ) concentration in the $0-10$ mol.\% range, allowing the determination of low doping concentration $(<0.1 \mathrm{~mol} . \%)$ with a high accuracy (error $<5 \%$ ). This result was used to determine the homogeneity of the doping ions with the $\mathrm{LaPO}_{4}$ matrix, similarly to the results obtained by Levin et al. in PbTe and GeTe or BiTe, by Sen et al. in silicate glasses, and by $\mathrm{Li}$ et al. in $\mathrm{SrH}_{2}: \mathrm{Eu}^{2+} \cdot{ }^{14-17}$ This method is highly powerful as long as the doping ions are paramagnetic and embedded within a matrix containing an element that can be analyzed easily by NMR $\left({ }^{31} \mathrm{P}\right.$ in our case).

In the present paper, we extend our work to other ${ }^{31} \mathrm{P}$-containing compounds doped with $\mathrm{Nd}^{3+}$ ions and study the influence of different structural factors on the $T_{1}$ variation. In addition to $\mathrm{LaPO}_{4}, \mathrm{YPO}_{4}$, the solid solution $\mathrm{Y}_{0.8} \mathrm{Sc}_{0.2} \mathrm{PO}_{4}$, the chloroalforsite $\mathrm{Ba}\left(\mathrm{PO}_{4}\right)_{3} \mathrm{Cl}$ and a phosphate glass are studied with $\mathrm{Nd}^{3+}$ concentration varying between 0 and $5.6 \mathrm{~mol} \%$. These compounds were chosen as they do not contain any paramagnetic element, so that only the $\mathrm{Nd}^{3+}$-doping will affect the relaxation time $T_{1}$. Moreover they present different crystallographic structures (summarized in Table 1) that will help us to understand how the distances and the orbital overlap influence $T_{1}$ with the Nd concentration variation. Our overall goal is to determine whether it is possible to predict the Nd concentration in an arbitrary P-containing compound. 
This paper is divided into two parts: in a first part, we present the synthesis and thorough characterizations of the structure of the different compounds; in a second part we present the results concerning their relaxation time $T_{1}$ as a function of the $\mathrm{Nd}^{3+}$ doping concentration and discuss them in the light of the material structure.

Table 1: Summary of the studied compounds, with their structural parameters. (\#) calculated values).

\begin{tabular}{|c|c|c|c|c|c|c|}
\hline & Space Group & $\begin{array}{l}\text { JCPDF } \\
\text { number }\end{array}$ & $\begin{array}{c}\text { Unit cell } \\
\text { parameters }\end{array}$ & $\begin{array}{l}\text { Density } \\
\left(\mathrm{g} / \mathrm{cm}^{3}\right)\end{array}$ & $\begin{array}{c}\text { Molecular } \\
\text { weight } \\
(\mathrm{g} / \mathrm{mol})\end{array}$ & $Z$ \\
\hline $\mathrm{LaPO}_{4}$ & $P 2_{1} / n$ & $\begin{array}{c}\text { 01-083- } \\
0651\end{array}$ & $\begin{array}{c}a=6.8313 \AA \\
b=7.0705 \AA \\
c=6.5034 \AA \\
\beta=103.270^{\circ} \\
V=306 \AA^{3}\end{array}$ & 5.33 & 234 & 4 \\
\hline $\mathrm{YPO}_{4}$ & I $4_{1} /$ amd & $\begin{array}{c}01-084- \\
0335\end{array}$ & $\begin{array}{c}a=6.8817 \AA \\
c=6.0177 \AA \\
V=285 \AA^{3}\end{array}$ & 4.28 & 184 & 4 \\
\hline $\mathrm{Y}_{0.8} \mathrm{Sc}_{0.2} \mathrm{PO}_{4}$ & I4 ${ }_{1} /$ amd & - & $\begin{array}{c}a^{\#}=6.8190 \AA, \\
c^{\#}=5.9742 \AA, \\
V^{\#}=278 \AA^{3}\end{array}$ & - & 175 & 4 \\
\hline $\mathrm{Ba} 5\left(\mathrm{PO}_{4}\right)_{3} \mathrm{Cl}$ & $P 6_{3} / m$ & $\begin{array}{c}01-070- \\
2318\end{array}$ & $\begin{array}{c}a=10.2840 \AA \\
c=7.6510 \AA \\
V=700 \AA^{3}\end{array}$ & 4.81 & 975 & 2 \\
\hline $\begin{array}{c}50 \mathrm{P}_{2} \mathrm{O}_{5}: 17 \mathrm{Mg} \\
\mathrm{O}: 33 \mathrm{Na}_{2} \mathrm{O}\end{array}$ & amorphous & - & - & $2.5^{18}$ & 98 & \\
\hline
\end{tabular}

\section{Synthesis and Characterization}

\subsection{Synthesis}

All precursors are purchased from Sigma-Aldrich. Except for pentasodium tripolyphosphate (TPP) and $\mathrm{NH}_{4} \mathrm{H}_{2} \mathrm{PO}_{4}$, they present purity over $99.9 \%$ to minimize the level of paramagnetic impurities (such as $\mathrm{Fe}^{3+}$ ions). The co-precipitation synthesis of the monazite phase $\mathrm{LaPO}_{4}$ doped with $\mathrm{Nd}^{3+}$ ions and of the xenotime phase $\mathrm{YPO}_{4}$ doped with $\mathrm{Nd}^{3+}$ are described in Maron et al. ${ }^{13}$ Briefly, $\mathrm{La}\left(\mathrm{NO}_{3}\right)_{3} \cdot 6 \mathrm{H}_{2} \mathrm{O}$ (or $\left.\mathrm{Y}\left(\mathrm{NO}_{3}\right)_{3} \cdot 6 \mathrm{H}_{2} \mathrm{O}\right), \mathrm{Nd}\left(\mathrm{NO}_{3}\right)_{3} \cdot 6 \mathrm{H}_{2} \mathrm{O}$ and an excess of pentasodium tripolyphosphate (TPP) are mixed together in a Teflon vessel. The 
mixture is placed for 3 hours at $90{ }^{\circ} \mathrm{C}$ in an oven. After filtration, the obtained powder is annealed at $1000{ }^{\circ} \mathrm{C}$ during 4 hours. For this study, the Nd doping concentration $x$ is comprised between 0 and 10 mol.\%. In the following, the doped compounds will be labeled $\mathrm{La}_{1-x} \mathrm{Nd}_{x} \mathrm{PO}_{4}$ and $\mathrm{Y}_{1-x} \mathrm{Nd}_{x} \mathrm{PO}_{4}$. Nd-doped $\mathrm{Y}_{0.8} \mathrm{Sc}_{0.2} \mathrm{PO}_{4}$ solid-solution is synthesized by a solid-state route: yttrium, scandium and neodymium oxides are mixed together with $\mathrm{NH}_{4} \mathrm{H}_{2} \mathrm{PO}_{4}$ in stoichiometric proportions. The mixture, previously homogenized by a planetary milling ( $250 \mathrm{rpm}, 20 \mathrm{~min}$ ), is heated at $1000{ }^{\circ} \mathrm{C}$ during 2 hours and then at $1550{ }^{\circ} \mathrm{C}$ during 8 hours. ${ }^{19}$ The nominal $\mathrm{Nd}$ concentration is set at $x=0,0.5$ and $1 \mathrm{~mol} \%$. The alforsite $\mathrm{Ba}_{5}\left(\mathrm{PO}_{4}\right)_{3} \mathrm{Cl}$ doped with $\mathrm{Nd}^{3+}$ is synthesized according to $\mathrm{Ju}$ et al ${ }^{20}$ : an excess of barium chloride is mixed together with $\mathrm{BaCO}_{3}$, $\mathrm{NH}_{4} \mathrm{H}_{2} \mathrm{PO}_{4}$ and $\mathrm{Nd}_{2} \mathrm{O}_{3}$ in a planetary mill (2 cycles, corresponding to 10 min grinding at 250 rpm spaced by $30 \mathrm{~s}$ pauses). The mixture is annealed at $950{ }^{\circ} \mathrm{C}$ for $3 \mathrm{hrs}$. As the doping induces a substitution of $\mathrm{Ba}^{2+}$ by $\mathrm{Nd}^{3+}$, the nominal $\mathrm{Nd}$ concentration $x$ is calculated taking into account the following chemical formula: $\mathrm{Ba}_{5(1-x)} \mathrm{Nd}_{5 x}\left(\mathrm{PO}_{4}\right)_{3} \mathrm{ClO}_{5 x / 2}$ and $x$ is set to 0,1 and 4 mol.\%. The obtained compounds will be labeled CAl-U (U for undoped), CAl-LD (LD for low doping) and CAl-HD (HD for high doping) respectively. Note that the charge compensation can occur through different mechanisms (such the creation of a Ba vacancy), as discussed in Ju et al. ${ }^{20}$ Regarding the Nd-doped metaphosphate glasses $\left(\mathrm{Q}^{2}\right.$ type), the different compositions are summarized in Table 2:

Table 2: Compositions of the different glasses synthesized and concentrations of Neodymium ion in mol. $\%$ and $\mathbf{~ m o l} / \mathrm{cm}^{3}$.

\begin{tabular}{|c|c|c|}
\hline Nominal composition & $x(\mathrm{~mol} . \%)$ & $C\left(\mathrm{~mol} / \mathrm{cm}^{3}\right)$ \\
\hline $500 \mathrm{P}_{2} \mathrm{O}_{5}: 170 \mathrm{MgO}: 330 \mathrm{Na}_{2} \mathrm{O}$ & 0 & 0 \\
\hline $499 \mathrm{P}_{2} \mathrm{O}_{5}: 167 \mathrm{MgO}: 333 \mathrm{Na}_{2} \mathrm{O}: 1 \mathrm{Nd}_{2} \mathrm{O}_{3}$ & 0.20 & $5.1 * 10^{-5}$ \\
\hline $498 \mathrm{P}_{2} \mathrm{O}_{5}: 167 \mathrm{MgO}: 331 \mathrm{Na}_{2} \mathrm{O}: 4 \mathrm{Nd}_{2} \mathrm{O}_{3}$ & 0.80 & $2.0^{*} 10^{-4}$ \\
\hline $492 \mathrm{P}_{2} \mathrm{O}_{5}: 166 \mathrm{MgO}: 328 \mathrm{Na}_{2} \mathrm{O}: 14 \mathrm{Nd}_{2} \mathrm{O}_{3}$ & 2.8 & $7.1 * 10^{-4}$ \\
\hline $489 \mathrm{P}_{2} \mathrm{O}_{5}: 165 \mathrm{MgO}: 325 \mathrm{Na}_{2} \mathrm{O}: 21 \mathrm{Nd}_{2} \mathrm{O}_{3}$ & 4.2 & $1.1 * 10^{-3}$ \\
\hline $485 \mathrm{P}_{2} \mathrm{O}_{5}: 164 \mathrm{MgO}: 323 \mathrm{Na}_{2} \mathrm{O}: 28 \mathrm{Nd}_{2} \mathrm{O}_{3}$ & 5.6 & $1.4 * 10^{-3}$ \\
\hline
\end{tabular}

These glasses are obtained by mixing $\mathrm{NH}_{4} \mathrm{H}_{2} \mathrm{PO}_{4}, \mathrm{MgO}, \mathrm{Na}_{2} \mathrm{CO}_{3}$ and $\mathrm{Nd}_{2} \mathrm{O}_{3}$ in a planetary mill. The powders are heated in a quartz crucible according to the following program: 2 hours at $250^{\circ} \mathrm{C}, 30 \mathrm{~min}$ at $800^{\circ} \mathrm{C}$ and 1 hour at $950^{\circ} \mathrm{C}$, with slow heating ramps (around $1^{\circ} \mathrm{C} / \mathrm{min}$ ). These different steps allow the progressive calcination of the reagents and the slow departure of $\mathrm{CO}_{2}$ and $\mathrm{NH}_{3}$. After the last step, the melted glass is quenched at room temperature. ${ }^{21}$ 


\subsection{Characterizations}

\subsubsection{NMR}

Magic-angle spinning (MAS) Solid-State NMR (SSNMR) experiments is performed using a Tecmag Apollo360 spectrometer and a $4 \mathrm{~mm}$ Bruker probe spinning at $15 \mathrm{kHz}$. The ${ }^{31} \mathrm{P}$ Larmor frequency (SF) is $145 \mathrm{MHz} .85 \% \mathrm{H}_{3} \mathrm{PO}_{4}$ is used as external reference for chemical shift. Fully relaxed conditions (repetition time equal to $5^{*} T_{1}$ ) are employed for all spectra, except mentioned. The spin-lattice relaxation time $T_{1}$ is measured by using a saturation-recovery method, using a sequence of $24 \pi / 2$ pulses (equal to $2.1 \mu \mathrm{s}$ ) spaced by $100 \mathrm{~ms}$. In this sequence, the repetition time is equal to $1 \mathrm{~s}$. FIDs are processed using NTNMR (Tecmag) software, applying a line broadening of $50 \mathrm{~Hz}$. The whole spectrum, including spinning sidebands, is considered for the $T_{1}$ determination. Astretehedenential, with $\beta=0.83$, is used for adjusting the relaxation recovery curves. As explained in our previous paper, since the best fitting $\beta$ values are close to each other for samples with different $\mathrm{Nd}$ concentrations, we decided to use a common $\beta=0.83$ to determine $T_{1}$ in order to make the comparison of the results for the different samples more consistent.

\subsubsection{Structural characterization}

Powder X-ray diffraction diagrams of the samples are systematically recorded using an X'Pert Philips diffractometer $(40 \mathrm{kV}, 40 \mathrm{~mA})$ with $\mathrm{CuK}_{\alpha}$ radiation $(\lambda=1.54056 \AA)$. The unit cell parameters are obtained by fitting the diagrams with Fullprof software. ${ }^{22,}{ }^{23}$ In crystals, distances between two phosphorus atoms are determined by Vesta software. ${ }^{24}$

The concentration of neodymium ions in the glass samples are determined by ICP-AES at Crealins (Lyon, France).

\subsubsection{UV/Vis Absorbance}

To control the homogeneity of the incorporation of the dopant into phosphate glasses, different UV/Vis spectra of a same sample are made on a Cary 50 Scan spectrophotometer from 200 to $1100 \mathrm{~nm}$.

\section{Results and discussion}

To understand the mechanism governing the ${ }^{31} \mathrm{P}$ relaxation in a paramagnetic environment, we synthesized different compounds and compared their relaxation rates with respect to the $\mathrm{LaPO}_{4}$ model system that we first investigated. ${ }^{13}$ First, yttrium phosphate, whose 
structure (xenotime) is different from $\mathrm{LaPO}_{4}$ (monazite) but which presents similar unit cell parameter, was directly compared to $\mathrm{LaPO}_{4}$ to determine the influence of the crystalline structure, and thus the orbital overlap, onto the ${ }^{31} \mathrm{P}$ relaxation rate. Second, the relaxation rates of two isomorphs $\left(\mathrm{YPO}_{4}\right.$ and $\mathrm{Y}_{0.8} \mathrm{Sc}_{0.2} \mathrm{PO}_{4}$ ) were compared to evaluate the influence of the unit cell parameters and consequently of the P-P interatomic distances. This study was extended to two other compounds: the alforsite, presenting a different crystalline structure and even more distinct P-P distances and a phosphate glass, presenting an amorphous structure and a larger P$\mathrm{P}$ distance distribution.

\subsection{Structural characterization}

\subsubsection{Nd-doped $\mathrm{LaPO}_{4}$}

A characteristic X-ray Powder Diffraction of $\mathrm{La}_{1-x} \mathrm{Nd}_{x} \mathrm{PO}_{4}$ is given in Figure 1a. It corresponds to the monazite structure. ${ }^{25}$ The unit cell parameter, calculated by Fullprof, ${ }^{22,23}$ decreases with the incorporation of Neodymium ion but its variation is scattered as we saw it in our previous paper (Figure 1b). ${ }^{13}$
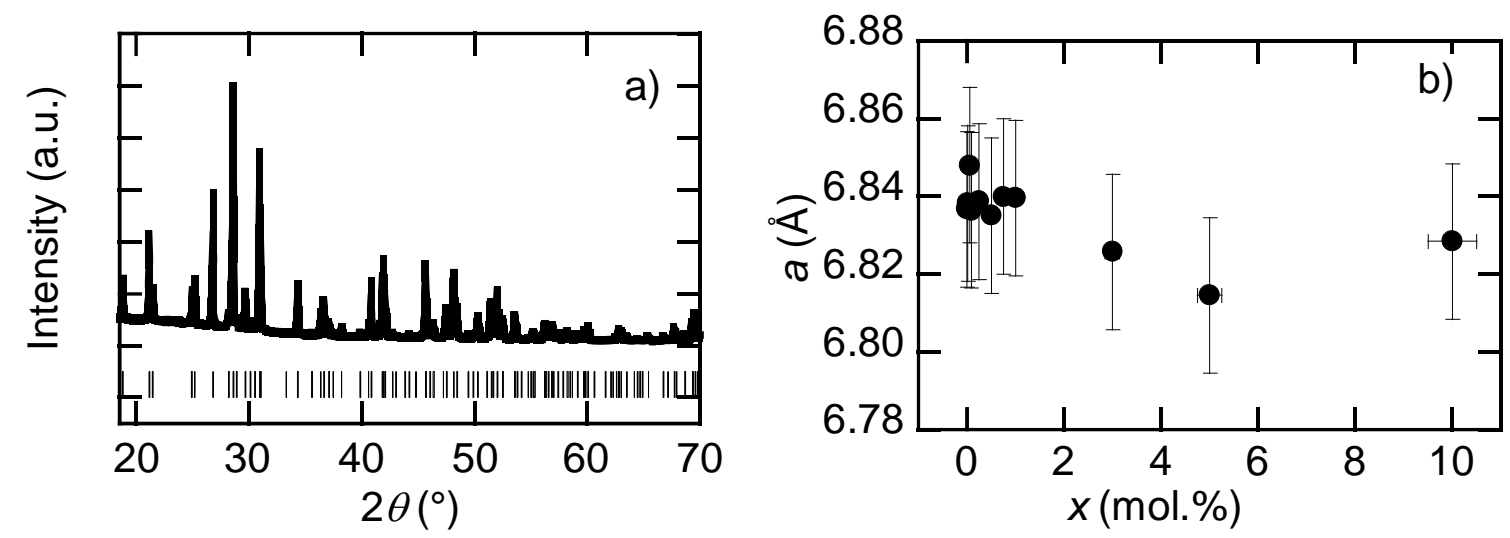

Figure 1: a) X-ray Powder Diffraction diagram of $\mathrm{LaPO}_{4}$ and as a reference the positions of the diffraction peaks of $\mathrm{LaPO}_{4}\left(\mathrm{JCPDF} \mathrm{n}^{\circ} 01-083-0651\right)$ and (b) variation of the unit cell parameter $a$ in $\mathrm{La}_{1-x} \mathrm{Nd}_{x} \mathrm{PO}_{4} \mathrm{as}$ function of the $\mathrm{Nd}^{3+}$ concentration $x$.

The SSNMR of $\mathrm{LaPO}_{4}: \mathrm{Nd}$ has been previously described ${ }^{13,26}$ and is here reported in SI (Figure SI-1). Briefly, with a short repetition time, paramagnetic peaks, associated to $\mathrm{P}$ in a vicinity of one $\mathrm{Nd}$ ions, can be observed between +40 and $-40 \mathrm{ppm}$. The evolution of the FWHM is shown as a function of the Nd concentration (Figure SI-2a). The FWHM of a paramagnetic peak increases linearly with $\mathrm{Nd}$ concentration, evidencing an increase of the disorder around $\mathrm{P}$. The area of a paramagnetic peak (at $\delta=+16 \mathrm{ppm}$ for $\mathrm{LaPO}_{4}$ ) also varies 
linearly with the increase of $\mathrm{Nd}$ doping, evidencing a good incorporation of $\mathrm{Nd}$ in the crystal structure (Figure SI-2b).

The doping concentration of our samples calculated from SS-NMR spectra, using the following law , $x$ :

$$
I_{k}=m * x^{k}(1-x)^{n-k}
$$

where $I_{k}$ is the intensity of paramagnetic peak at $+16 \mathrm{ppm} m$ is the number of configurations that can give rise to a specific peak, $k$ is the number of $\mathrm{Nd}^{3+}$ interacting with the ${ }^{31} \mathrm{P}$ nucleus for the specific peak, $n$ is the total number of sites into which $\mathrm{Nd}^{3+}$ can enter and cause a specific paramagnetically shifted peak (equal to 7 here for the 7 distinct first-shell ${ }^{31} \mathrm{P}-\mathrm{Nd}^{3+}$

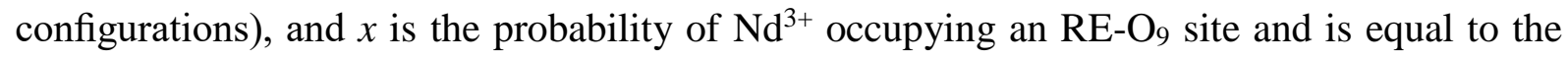
concentration of $\mathrm{Nd}^{3+}$ (out of total $\mathrm{Nd}+\mathrm{La}$ ). ${ }^{27,28}$ As shown on Figure SI-3, Nd concentration determined by NMR linearly increases and matches the nominal $\mathrm{Nd}$ concentration.

\subsubsection{Influence of the crystal structure: xenotime Nd-doped $\mathrm{YPO}_{4}$}

Figure 2a shows a $\mathrm{X}$-ray Powder Diffraction diagram of $\mathrm{Y}_{0.999} \mathrm{Nd}_{0.001} \mathrm{PO}_{4}$. It is characteristic of the tetragonal xenotime structure with the $I 4_{1} /$ amd space group. ${ }^{25}$ The different $\mathrm{Y}_{1-x} \mathrm{Nd}_{x} \mathrm{PO}_{4}$ compounds, for $0 \leq x \leq 0.2$, crystallize in the same tetragonal crystalline structure. ${ }^{29}$ The typical unit cell parameter $a$ is determined in the whole range of doping concentration $x$ (Figure 2b). Its variation is scattered again, as seen in Maron et al. for $\mathrm{LaPO}_{4}{ }^{13}$, evidencing the resolution limit of diffraction in the determination of doping concentration. Above $x=8 \mathrm{~mol}$. \%, the unit cell parameters appears constant, showing a limit of solubility. 

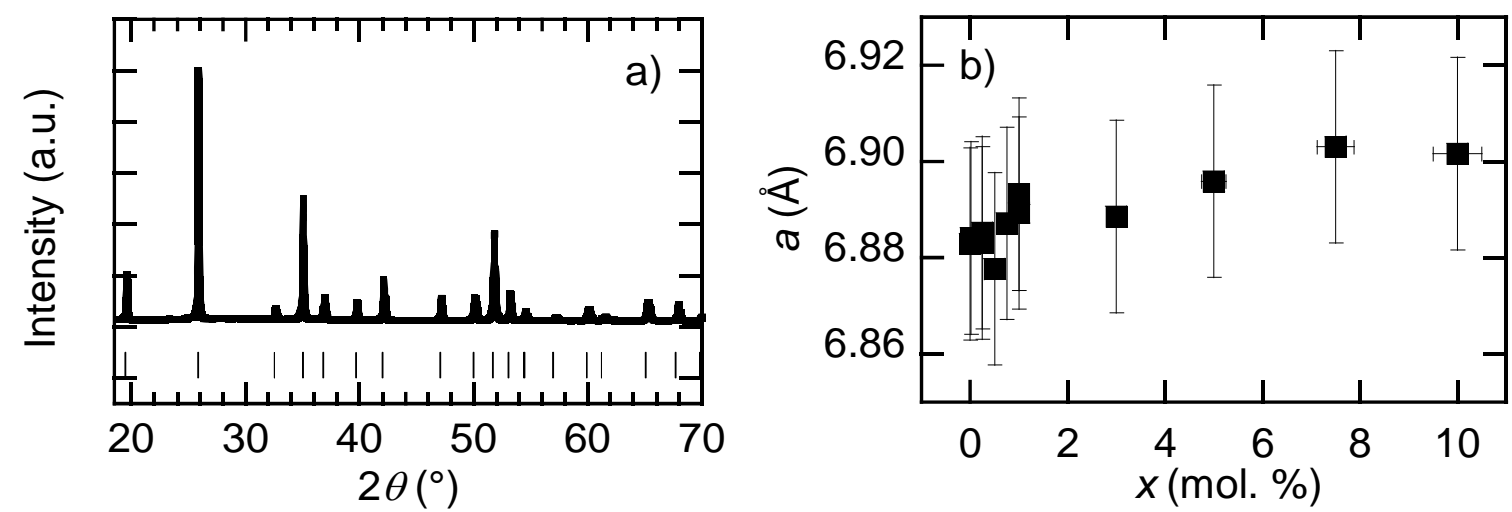

Figure 2: a) X-ray Powder Diffraction of $\mathrm{Y}_{0.999} \mathrm{Nd}_{0.001} \mathrm{PO}_{4}$ and as a reference the positions of the diffraction peaks of $\mathrm{YPO}_{4}\left(\mathrm{JCPDF} \mathrm{n}^{\circ} 01-084-0335\right)$ and (b) variation of the unit cell parameter $a$ in $\mathrm{Y}_{1-x} \mathrm{Nd}_{x} \mathrm{PO}_{4}$ as a function of the $\mathrm{Nd}^{3+}$ concentration $x$.

The SSNMR spectrum of $\mathrm{Y}_{0.9975} \mathrm{Nd}_{0.0025} \mathrm{PO}_{4}$ is reported on Figure 3 with a long repetition delay. A single peak at -9.8 ppm is observed, equivalent to Palke and Stebbins at $12 \mathrm{ppm}$ or Briche et al. at around $-10.5 \mathrm{ppm} .{ }^{26}, 30$ No paramagnetically shifted peaks, corresponding $t{ }^{31} \mathrm{P}$ interacting with paramagnetic $\mathrm{Nd}^{3+}$ ions in the vicinity, are observed. In order to observe such peaks, very short repetition delay should be used ${ }^{13,26,31}$

The spectrum of $\mathrm{Y}_{0.925} \mathrm{Nd}_{0.075} \mathrm{PO}_{4}$ evidences a peak at the same chemical shift, but its Full Width at High Maximum (FWHM) appears much broader due to the strong anisotropy of the chemical shift.

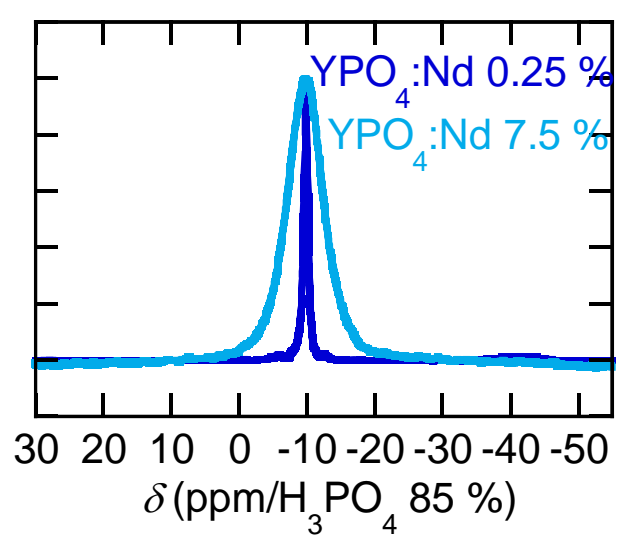

Figure 3: Solid-State NMR spectra at $15 \mathrm{kHz}$ of $\mathrm{Y}_{0.9975} \mathrm{Nd}_{0.0025} \mathrm{PO}_{4}$ (blue) and $\mathrm{Y}_{0.925} \mathrm{Nd}_{0.075} \mathrm{PO}_{4}$ (light blue).

As in $\mathrm{LaPO}_{4}$, paramagnetically shifted peaks can be observed in $\mathrm{YPO}_{4}$ and are labelled A to $\mathrm{C}$, in reference to the $\mathrm{LaPO}_{4}$ spectrum (Figure SI-4). ${ }^{26,27}$ The evolution of the area and the FWHM as a function of Nd doping concentration in $\mathrm{YPO}_{4}$ is presented in SI (Figure SI-5 a and b). The area of a paramagnetic peak $\left(\delta=+36\right.$ ppm for $\left.\mathrm{YPO}_{4}\right)$ varies linearly, as in $\mathrm{LaPO}_{4}$, indicating that $\mathrm{Nd}$ is well-incorporated inside $\mathrm{YPO}_{4}$.

As the doping concentration of $\mathrm{Nd}$ increases, the probability of having $\mathrm{P}$ with two $\mathrm{Nd}$ ions in its vicinity increases. One should then observe paramagnetic peaks that are even more 
shifted: for instance, in $\mathrm{YPO}_{4}$, the peak at $-72 \mathrm{ppm}$ should be observed. However, in our case, our interest lies in low $\mathrm{Nd}$ doping concentration. So, for further characterizations, and especially relaxation measurements, only the region between +60 to $-40 \mathrm{ppm}$ will be considered.

As for $\mathrm{LaPO}_{4}$, the doping level of our samples is checked by the application of the formulae given by Palke et al. in 2013: ${ }^{27}$

$$
I_{k}=4 * x(1-x)^{5}
$$

As shown on Figure SI-6, Nd concentration determined by NMR linearly increases and matches the nominal $\mathrm{Nd}$ concentration.

\subsubsection{Influence of lattice parameter: Nd-doped $\mathrm{Y}_{0.8} \mathrm{Sc}_{0.2} \mathrm{PO}_{4}$}

In order to study the influence of the lattice parameter on the nuclear relaxation, compounds with the same structure but different lattice parameters were synthesized. $\mathrm{YPO}_{4}$, $\mathrm{ScPO}_{4}$ were chosen, as well as the $\mathrm{Y}_{0.8} \mathrm{Sc}_{0.2} \mathrm{PO}_{4}$ solid solution. Undoped compounds were synthesized to verify the formation of the $\mathrm{Y}_{0.8} \mathrm{Sc}_{0.2} \mathrm{PO}_{4}$ solid solution. On Figure 4a are reported the X-ray diffraction diagrams of undoped $\mathrm{YPO}_{4}, \mathrm{ScPO}_{4}$ and $\mathrm{Y}_{0.8} \mathrm{Sc}_{0.2} \mathrm{PO}_{4}$. All of these compounds crystallize in the same space group. Note that $\mathrm{ScPO}_{4}$ presents an amorphous phase at $2 \theta \sim 25^{\circ}$. When zooming on an arbitrary diffraction peak (Figure 4b), one can observe a diffraction peak shift related to a difference in terms of ionic radius. In $\mathrm{YPO}_{4}$, where $\mathrm{Y}^{3+}$ ions have an ionic radius of $1.02 \AA$, the unit cell parameter is worth $a=6.8817 \AA$ (resp. $c=6.0177 \AA$ ); whereas in $\mathrm{ScPO}_{4}$, where $\mathrm{Sc}^{3+}$ ions have an ionic radius of $0.87 \AA$, it is $a=6.5680 \AA$ (resp. $c=5.8000 \AA$ ). Taking into account these different values, the unit cell parameters of $\mathrm{Y}_{0.8} \mathrm{Sc}_{0.2} \mathrm{PO}_{4}$ are calculated: $a=6.8190 \AA$ and $c=5.9742 \AA$. The experimental values are $a=6.8117 \AA$ and $c=5.9642 \AA$, confirming the formation of the expected solid solution. 

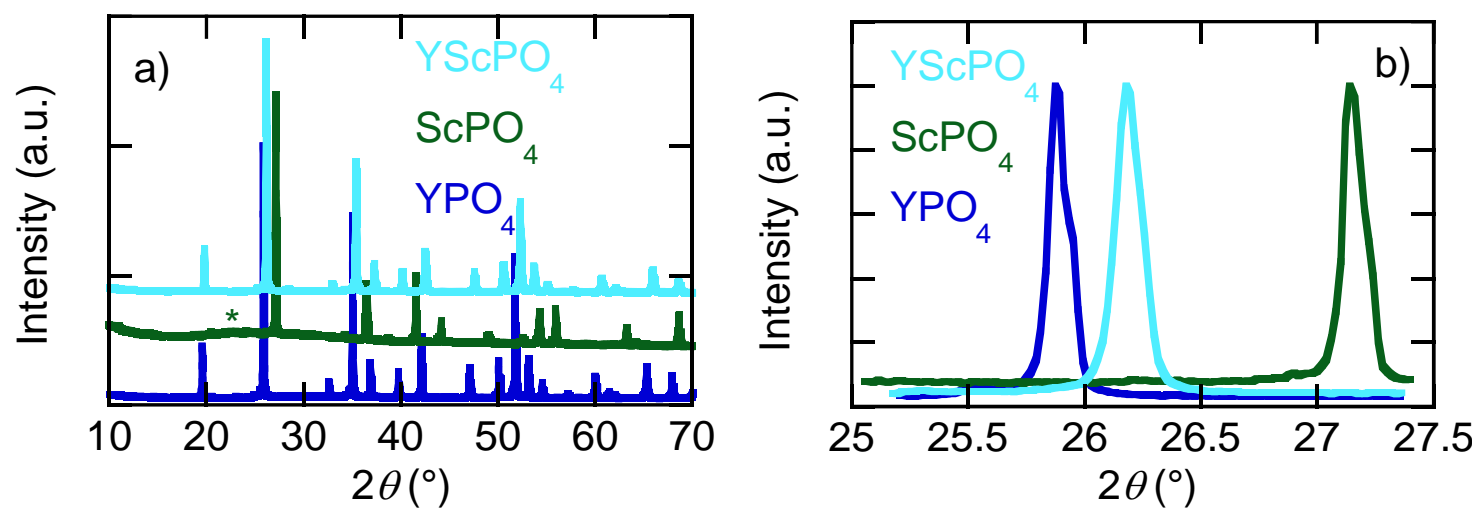

Figure 4: X-ray Powder Diffraction diagram of $\mathrm{Y}_{0.8} \mathrm{Sc}_{0.2} \mathrm{PO}_{4}\left(\mathrm{cyan}\right.$, noted $\left.\mathrm{YScPO}_{4}\right), \mathrm{ScPO}_{4}\left(\right.$ green) and $\mathrm{YPO}_{4}$ (blue). Whole diagram (a) and zoom on the $(2,0,0)$ peak $(b)$. On a), the star corresponds to an amorphous unidentified phase.

On Figure 5, the NMR spectrum of $\mathrm{ScPO}_{4}$ presents two peaks: the first one at around $12 \mathrm{ppm}$ attributed to our product and another one, much broader, at around $-40 \mathrm{ppm}$ which confirms the presence of an amorphous phase that we have not been able to remove playing on stoichiometry and calcination temperature. The solid-state NMR spectrum of $\mathrm{Y}_{0.8} \mathrm{Sc}_{0.2} \mathrm{PO}_{4}$ exhibits two peaks: the first at -9.8 ppm corresponding to the chemical shift of ${ }^{31} \mathrm{P}$ in the vicinity of $\mathrm{Y}$ atoms, as found in $\mathrm{YPO}_{4}$, and the second peak at $-11.6 \mathrm{ppm}$ corresponding to the chemical shift of ${ }^{31} \mathrm{P}$ in the vicinity of $\mathrm{Sc}$ atoms, as found in $\mathrm{ScPO}_{4}$. The deconvolution processed by DMFit $^{32}$ confirms the good relative proportion between Yttrium and Scandium (not shown). The interpretation of such an observation of two separate contributions corresponding to the two phases ( $\mathrm{YPO}_{4}$ and $\mathrm{ScPO}_{4}$ respectively) plays in favor of a phase segregation. Nevertheless, this is contradictory with the result from XRD characterization that follows the Vegard's law and thus tends to demonstrate the solid solution. An interpretation could be that some segregation of the Sc ions occurs leading to $\mathrm{P}(\mathrm{Sc}) 6$ units homogeneously dispersed in the host $\mathrm{YPO}_{4}$ phase. Nevertheless, confirmation of this hypothesis goes beyond the scope of this paper, and the $\mathrm{Y}_{0.8} \mathrm{Sc}_{0.2} \mathrm{PO}_{4}$ compound should thus be considered with precautions in the further discussion. 


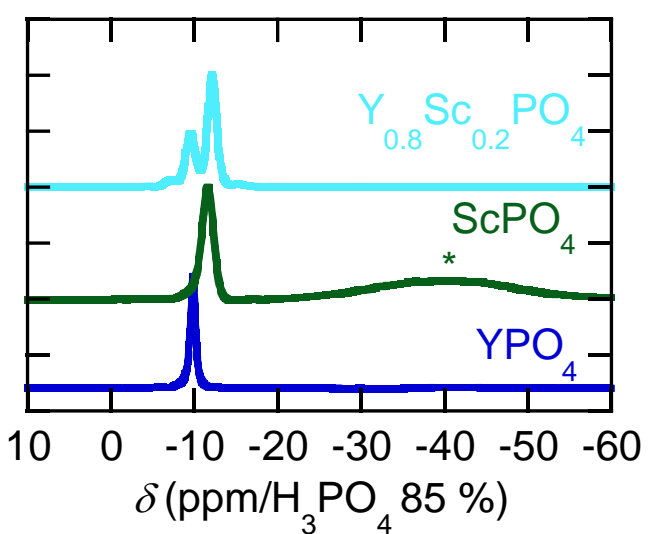

Figure 5: $\mathrm{SSNMR}_{\text {at }} \omega_{\text {rot }}=15 \mathrm{kHz}$ of $\mathrm{YPO}_{4}(\mathrm{blue}), \mathrm{ScPO}_{4}$ (green) and the $\mathrm{Y}_{0.8} \mathrm{Sc}_{0.2} \mathrm{PO}_{4}$ compound (cyan). The star (*) is an unknown phase.

\subsubsection{Influence of structure: $\mathrm{Nd}$-doped alforsite $\mathrm{Ba}_{5}\left(\mathrm{PO}_{4}\right)_{3} \mathrm{Cl}$}

The $\mathrm{Ba}_{5}\left(\mathrm{PO}_{4}\right)_{3} \mathrm{Cl}$ alforsite belongs to the apatite family. It crystallizes in the hexagonal system $\left(P 6_{3} / m\right)$ with typical unit cell parameters of $10.2840 \AA$ for $a$ and $7.6510 \AA$ for $c$, i.e. very different than the ones of $\mathrm{LaPO}_{4} . \mathrm{Ba}_{5(1-x)} \mathrm{Nd}_{5 x}\left(\mathrm{PO}_{4}\right)_{3} \mathrm{ClO}_{5 x / 2}$ was doped with different $\mathrm{Nd}$ concentrations: $x=0,0.01$ and 0.04. These compounds are called CAl-U, CAl-LD and CAl$\mathrm{HD}$, respectively. Our XRD results exhibit the formation of a pure alforsite phase for all doping concentrations (Figure 6). No impurity phase is detected.
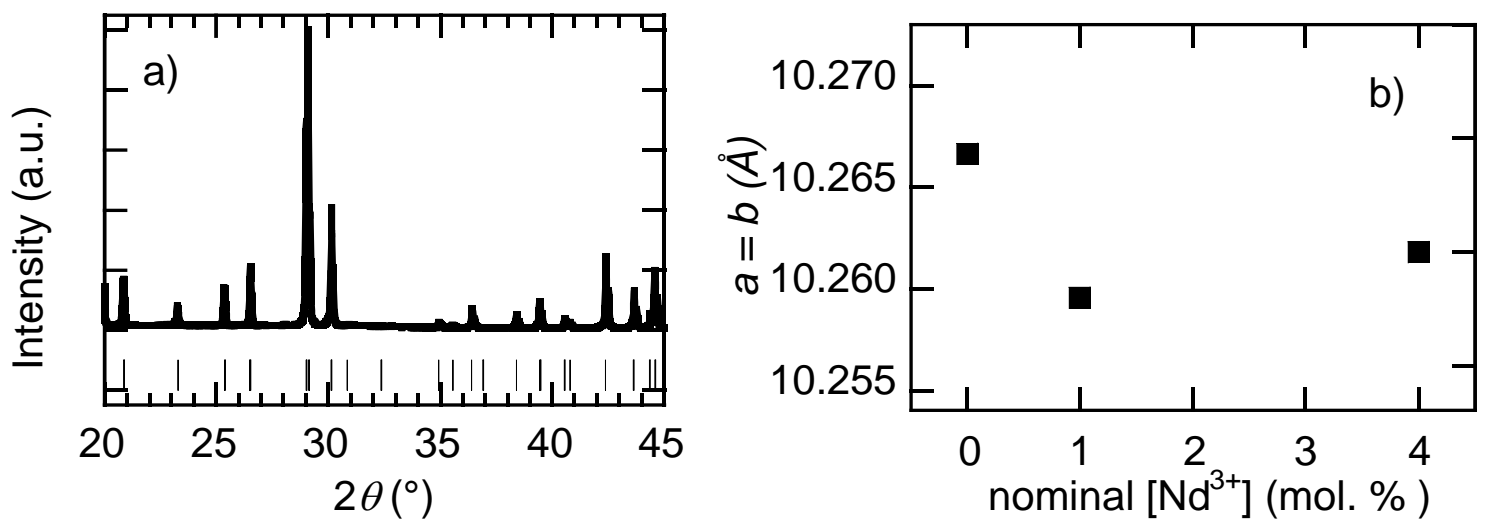

Figure 6: a): X-ray Powder Diffraction diagram of the HD sample and JCPDF file 01-070-2318 of alforsite. b): Variation of the unit cell parameters $a=b$ as a function of the nominal Neodymium concentration in $\mathrm{Ba} 5\left(\mathrm{PO}_{4}\right)_{3} \mathrm{Cl}$.

The three doping composition of alforsite do not respect the Vegard's law, but at this step we are unable to know if it arise from uncertainty of measurements or a weakness in $\mathrm{Nd}$ incorporation (Figure 6b).

Figure 7 presents two solid-state NMR spectra of chloroalforsite (undoped and with 4\% of neodymium ion). On the undoped spectra, the first peak at around $0.6 \mathrm{ppm}$ corresponds to $\mathrm{Ba}_{5}\left(\mathrm{PO}_{4}\right)_{3} \mathrm{Cl}$, whereas the minor peak at around $1.6 \mathrm{ppm}$ is attributed to $\beta$-tribaryum 
phosphate. ${ }^{33}$ The spectrum of CAl-HD exhibits a broader peak, centered at $2.5 \mathrm{ppm}$. The increase of the FWHM, as well as the chemical shift, indicates a change in the P environment.

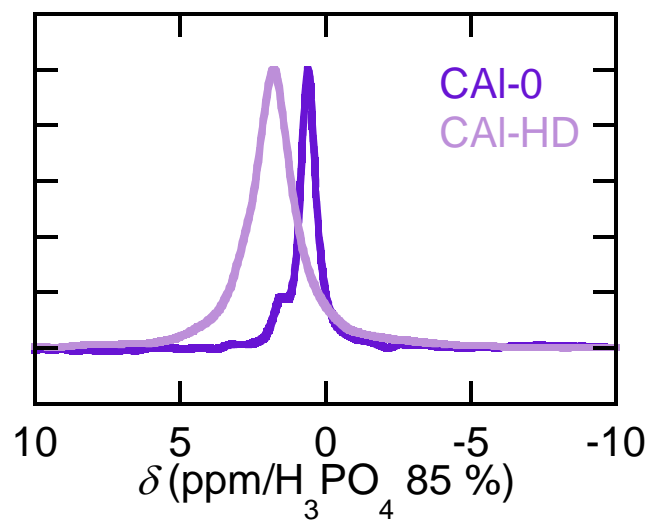

Figure 7: SSNMR ( $\left.\omega_{\mathrm{r}}=15 \mathrm{kHz}\right)$ of two alforsite compounds: CAl-U (purple) and CAl-HD (light purple).

\subsubsection{Influence of structure: Phosphate glasses}

A series of metaphosphate glasses (characterized by a theoretical $\mathrm{Q}^{2}$ proportion of $100 \%$ ) were synthesized according to Pukhaya et al. ${ }^{21} \mathrm{X}$-ray Powder Diffraction confirms the amorphous nature of the different compounds, by the absence of Bragg peaks (not shown). NMR spectroscopy exhibits a broad and intense peak at around -22 ppm (Figure 8), attributed to ${ }^{31} \mathrm{P}$ in $\mathrm{Q}^{2}$ sites. ${ }^{34} \mathrm{~A}$ second peak at around $-9 \mathrm{ppm}$ representing less than $10 \%$ is attributed to the presence of $\mathrm{Q}^{1}$ sites, probably resulting to some impurities in our precursors. Due to the broad peak at -22 ppm, we could not see paramagnetic peak even with a repetition time of $50 \mathrm{~ms}$ (Figure SI-7).

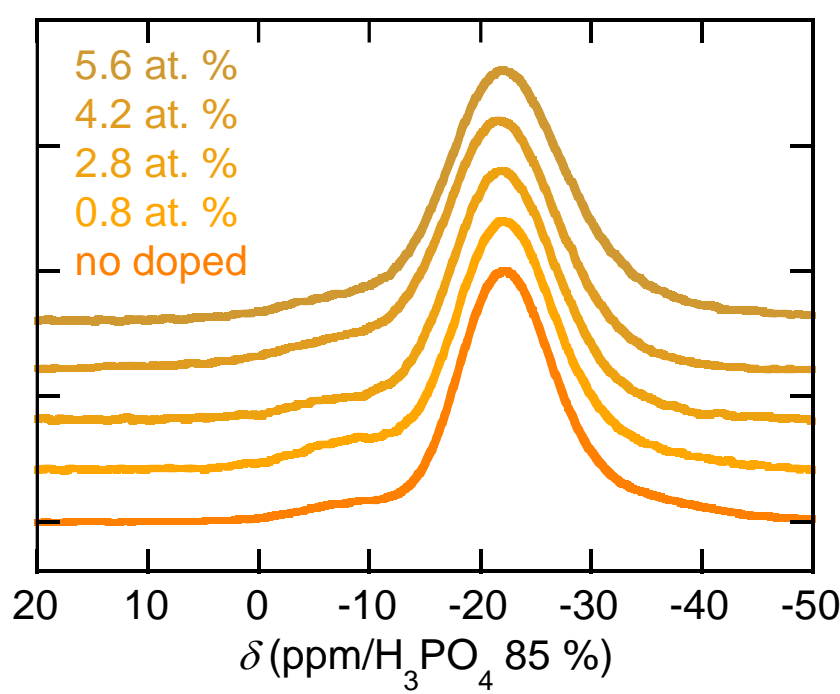

Figure 8: SSNMR spectra of metaphosphate glasses at $\omega_{\mathrm{r}}=15 \mathrm{kHz}$. From top to bottom, with 5.6, 4.2, 2.8, 0.8 and 0 mol. \% of $\mathrm{Nd}^{3+}$.

Absorption spectra were recorded for the different $\mathrm{Nd}$ concentrations, evidencing the different optical transitions of $\mathrm{Nd}^{3+}$ (Figure 9a). 

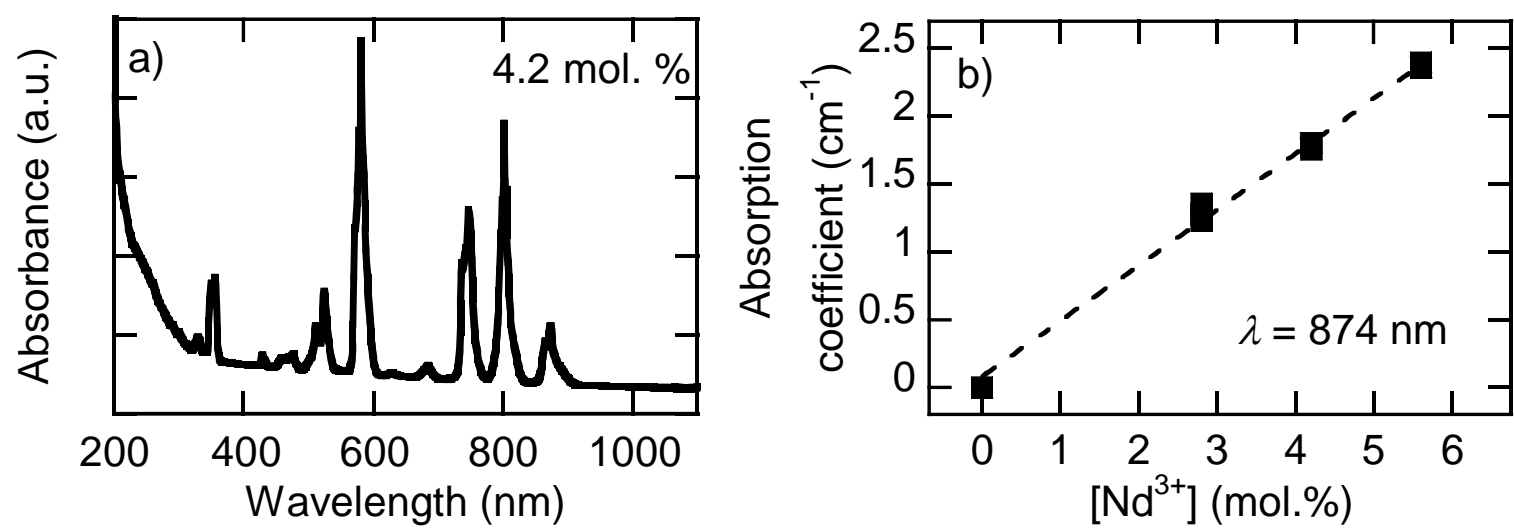

Figure 9: a): Absorbance of a phosphate glass doped by 4.2 mol. \% of Neodymium. The main absorption peaks at $590 \mathrm{~nm}, 750 \mathrm{~nm}$ and $800 \mathrm{~nm}$ correspond to the ${ }^{4} I_{9 / 2} \rightarrow\left({ }^{2} G_{5 / 2},{ }^{2} G_{7 / 2}\right),{ }^{4} I_{9 / 2} \rightarrow\left({ }^{4} \mathbf{F}_{7 / 2},{ }^{4} S_{3 / 2}\right)$ and ${ }^{4} \mathbf{I}_{9 / 2} \rightarrow\left({ }^{4} \mathbf{F}_{5 / 2},{ }^{2} \mathbf{H}_{9 / 2}\right)$ transitions, respectively. ${ }^{35}$ b): Absorption coefficient for different Neodymium concentrations in the phosphate glass.

The values of absorbance for different Neodymium contents at $874 \mathrm{~nm}$ are reported on Figure 9b. Taking into account the good incorporation of $\mathrm{Nd}$ in the sample containing $5.6 \mathrm{~mol}$. $\%$, as observed by elementary analysis, and the linear variation of the absorption coefficient in the whole doping range, one can state that $\mathrm{Nd}^{3+}$ ions are introduced in the expected proportion into the different glasses for concentrations ranging from 0 to $5.6 \mathrm{~mol}$. \%. Measurements were repeated on different points of the samples to confirm their spatial homogeneity.

\subsection{Relaxation measurements}

\subsubsection{Relaxation mechanism}

The relaxation rate of ${ }^{31} \mathrm{P}$ atoms is plotted on Figure $\mathbf{1 0}$ as a function of the $\mathrm{Nd}^{3+}$ concentration for the different compounds: $\mathrm{LaPO}_{4}$ crystal, $\mathrm{YPO}_{4}$ crystal, the $\mathrm{Y}_{0.8} \mathrm{Sc}_{0.2} \mathrm{PO}_{4}$ compound, $\mathrm{Ba}_{5}\left(\mathrm{PO}_{4}\right)_{3} \mathrm{Cl}$ crystal and the $\mathrm{Na}_{2} \mathrm{O}: \mathrm{MgO}: \mathrm{P}_{2} \mathrm{O}_{5}$ glass. The more paramagnetic $\mathrm{Nd}^{3+}$ ions in the matrix, the faster the relaxation of ${ }^{31} \mathrm{P}$ atoms. In all compounds except the alforsite, the variation of ${ }^{31} \mathrm{P}$ relaxation rate is significant and linear with the $\mathrm{Nd}$ content, evidencing a homogeneous distribution of the doping ions within the various matrices. ${ }^{13,14,36}$ Note that the $\mathrm{x}$-axis, corresponding to the $\mathrm{Nd}$ concentration $C$ has been plotted in $\mathrm{mol} / \mathrm{cm}^{3}$ in order to take into account the density of the different compounds and thus to compare them. 


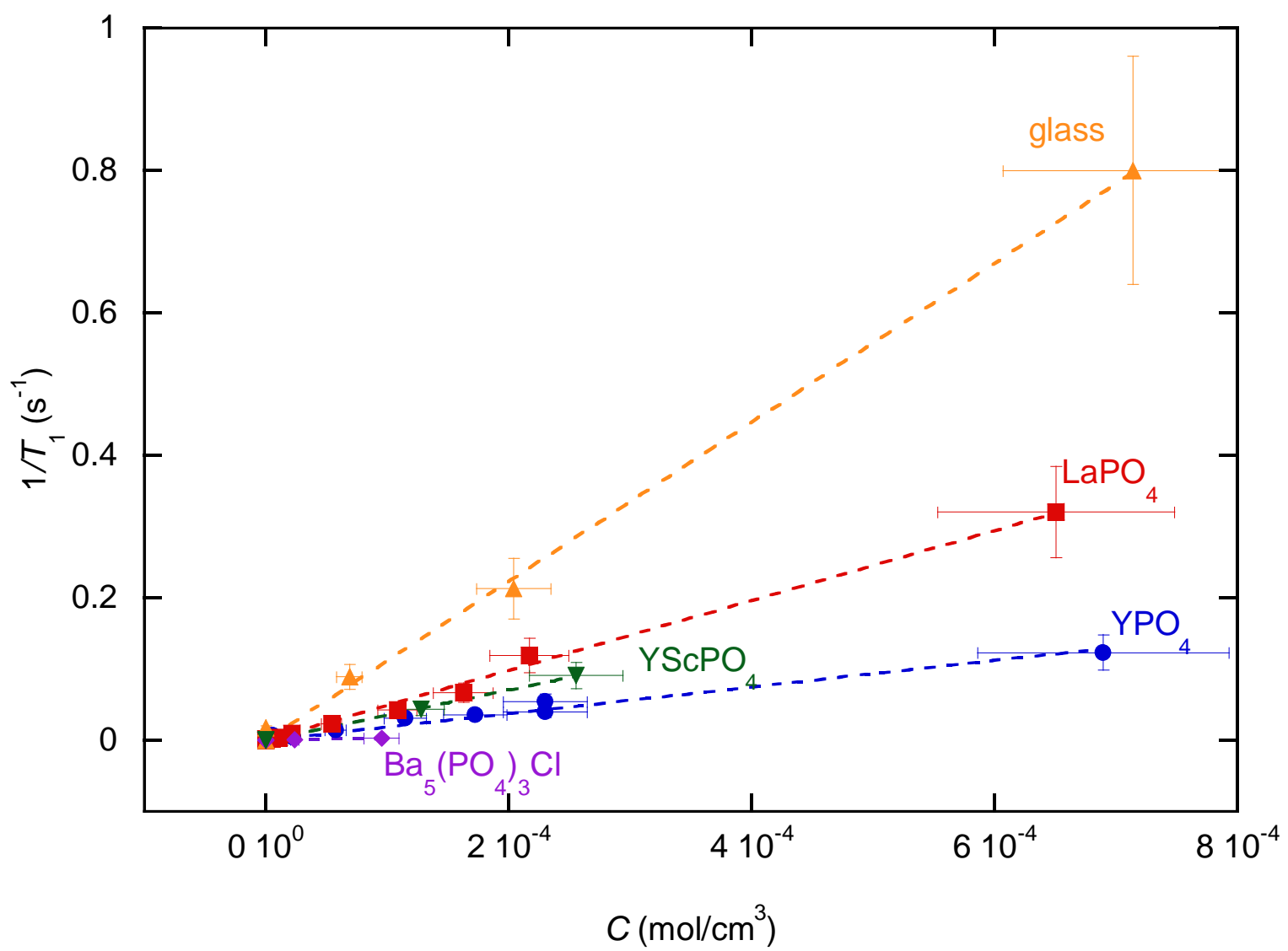

Figure 10: Comparison of the ${ }^{31} \mathrm{P}$ relaxation rate for $\mathrm{LaPO}_{4}$ (red squares), $\mathrm{YPO}_{4}$ (blue circles), the $\mathrm{Y}_{0.8} \mathrm{Sc}_{0.2} \mathrm{PO}_{4}$ compound (green triangles), $\mathrm{Ba}\left(\mathrm{PO}_{4}\right)_{3} \mathrm{Cl}$ (purple diamonds) and phosphate glass (orange triangles) in function of Neodymium concentration $C$ (in $\mathrm{mol} / \mathrm{cm}^{3}$ ). The different linear regressions are respectively: $1 / T_{1}=4.9 * 10^{2} * C$ for $\mathrm{LaPO}_{4}, 1.9 * 10^{2} * C$ for $\mathrm{YPO}_{4}, 3.5 * 10^{2} * C$ for $\mathrm{Y}_{0.8} \mathrm{Sc}_{0.2} \mathrm{PO}_{4}, 2.7 * 10^{1} * C$ for $\mathrm{Ba}_{5}\left(\mathrm{PO}_{4}\right)_{3} \mathrm{Cl}$ and $1.1 * 10^{3 *} C$ for the metaphosphate glass with $T_{1}$ in $\mathrm{s}^{-1}$ and $C$ in $\mathrm{mol} / \mathrm{cm}^{3}$. A zoom for $0 \leq x \leq 2.5 * 10^{-4} \mathrm{~mol} / \mathrm{cm}^{3}$ of this figure is shown in SI-8.

There are two main channels of desexcitation for a nucleus in the vicinity of a paramagnetic impurity: the direct relaxation and the relaxation via spin diffusion. ${ }^{37}$ In dilute materials, the spin diffusion mechanism is predominant; whereas, in highly-doped systems, the direct relaxation should be considered. The latter corresponds to a dipolar coupling between the ${ }^{31} \mathrm{P}$ $\left(I=1 / 2\right.$, with a Larmor frequency $\left.\omega_{\mathrm{I}}\right)$ and a paramagnetic ion characterized by a momentum $J$, at a Larmor frequeny $\omega_{\mathrm{J}}$ and situated at a distance $d$ from the Phosphor. The nucleus relaxation time $T_{1}$ can be written as: ${ }^{37}$

$$
\frac{1}{T_{1}}=\left(\frac{\mu_{0}}{4 \pi}\right)^{2} \frac{1}{15} J(J+1) \frac{\hbar^{2} \gamma_{\mathrm{I}}^{2} \gamma_{\mathrm{J}}^{2}}{d^{6}}\left[\frac{6 \tau_{1}}{1+\omega_{\mathrm{I}}^{2} \tau_{1}^{2}}+\frac{14 \tau_{2}}{1+\omega_{\mathrm{J}}^{2} \tau_{2}^{2}}\right]
$$

where $\gamma_{\mathrm{T}}\left(\right.$ resp. $\left.\gamma_{\mathrm{J}}\right)$ is the gyromagnetic ratio of Phosphor (resp. the electron), and $\tau_{1}$ (resp. $\tau_{2}$ ) is the electronic spin-lattice (resp. spin-spin) relaxation time.

The second regime is the relaxation through spin diffusion. It can be separated into two regimes: one, predominant at low temperature, is known as the diffusion limited regime; and the other, 
occurring at higher temperature, is called the fast spin diffusion (FSD) regime. In the latter case, the relaxation time $T_{1}^{\mathrm{FSD}}$ can be written as:

$$
\frac{1}{T_{1}^{\mathrm{FSD}}}=A \frac{C \tau_{1}}{1+\omega_{\mathrm{I}}^{2} \tau_{1}^{2}}
$$

with $x$ the molar fraction of paramagnetic ions, and where $A$ is

$$
A=\frac{8}{15} \pi\left(\frac{\mu_{0}}{4 \pi}\right)^{2} \frac{N \hbar^{2} \gamma_{\mathrm{I}}^{2} \gamma_{\mathrm{J}}^{2} J(J+1)}{V b_{2}^{3}}
$$

and only depends on the parameter $b_{2}$, described in Goudemond et al. ${ }^{38}$ and which corresponds to the distance below which the nuclear spin diffusion is ineffective. At room temperature $\tau_{1}\left(\mathrm{Nd}^{3+}\right)<1 \mathrm{~ns}$, one can assume $\omega_{\mathrm{I}}^{2} \tau_{1}^{2}<<1^{13}$, so:

$$
\frac{1}{T_{1}^{\mathrm{FSD}}}=A C \tau_{1}
$$

As the experimental $1 / T_{1}$ variation is linear with the $\mathrm{Nd}$ molar concentration (Figure 10), it can be determined that the relaxation mechanism is a fast spin diffusion regime, as already found in Maron et al. ${ }^{13}$

Taking into account the slopes of the linear fits shown on Figure 10, as well as Eq.3 and Eq.4 and the structural characteristics indicated on Table 1, it is possible to calculate the electronic relaxation times $\tau_{1}$ for the crystalline compounds: $\tau_{1}\left(\mathrm{LaPO}_{4}: \mathrm{Nd}\right)=11$ ps with $b_{2}=13.6 \AA$ and $\tau_{1}\left(\mathrm{YPO}_{4}: \mathrm{Nd}\right)=10$ ps with $b_{2}=18.8 \AA$ A. $\tau_{1}\left(\mathrm{LaPO}_{4}: \mathrm{Nd}\right)$ and $\tau_{1}\left(\mathrm{YPO}_{4}: \mathrm{Nd}\right)$ are very short, due to spin-orbit coupling. This explains why, in Electron Spin Resonance (ESR) experiments, $\mathrm{Nd}^{3+}$ signature should be looked for at low temperature (usually below $40 \mathrm{~K}$ ). ${ }^{11}, 13$ The value obtained for $\mathrm{LaPO}_{4} \mathrm{Nd}$ is identical to the one calculated at low concentration and reported in Maron et al. ${ }^{13}$

The question that we now want to address is the one of the factor governing the slope of the line i.e. the $A$ coefficient, and how it could be correlated with the material structure.

\subsubsection{Influence of the crystal structure}

To determine whether the crystalline structure, i.e. the Nd-P distances and the orbital overlap, has an influence of the relaxation rates, one can first compare the slopes of $\mathrm{LaPO}_{4}$ and $\mathrm{YPO}_{4}$ compounds in Figure 10. $\mathrm{LaPO}_{4}: \mathrm{Nd}$ and $\mathrm{YPO}_{4}: \mathrm{Nd}$ present similar unit cell parameters $\left(a_{\mathrm{LaPO} 4}=6.8367 \AA, \quad b_{\mathrm{LaPO} 4}=7.0746 \AA, \quad c_{\mathrm{LaPO} 4}=6.5074 \AA \quad\right.$ and $\quad a_{\mathrm{YPO} 4}=6.8817 \AA$, $c_{\text {YPO4 }}=6.0177 \AA$ ), inducing similar Nd-P distances (average Nd-P distance in $\mathrm{LaPO}_{4}=3.59 \AA$ and in $\mathrm{YPO}_{4}=3.51 \AA$, calculated using the Gretep software ${ }^{39}$ ); however, they crystallize in 
different structures (monazite and xenotime, resp.), showing different orbital overlap. Regarding the variation of the relaxation rate as a function of the $\mathrm{Nd}$ concentration, it seems that this parameter has an impact on the ${ }^{31} \mathrm{P}$ nuclear relaxation. Indeed the relaxation rate is faster for $\mathrm{LaPO}_{4}: \mathrm{Nd}$ than for $\mathrm{YPO}_{4}: \mathrm{Nd}$.

Regarding the direct influence of the Nd-P distances, the comparison between $\mathrm{YPO}_{4}$ and the solid solution $\mathrm{Y}_{0.8} \mathrm{Sc}_{0.2} \mathrm{PO}_{4}$ is more relevant. Indeed, $\mathrm{YPO}_{4}$ and $\mathrm{Y}_{0.8} \mathrm{Sc}_{0.2} \mathrm{PO}_{4}$ crystallize in the same crystallographic group but they present an absolute variation of $2 \%$ of the unit cell parameters. In $\mathrm{YPO}_{4}$, there are two types of Nd-P distances: $3.014 \AA$ ( 2 distances) and $3.765 \AA$ (4 distances) for an average distance of $3.515 \AA$, as calculated with Gretep software. ${ }^{39}$ In $\mathrm{Y}_{0.8} \mathrm{Sc}_{0.2} \mathrm{PO}_{4}$, these distances are $2.985 \AA$ and $3.720 \AA$, giving an average distance of $3.475 \AA$. The relaxation rates of $\mathrm{YPO}_{4}$ and $\mathrm{Y}_{0.8} \mathrm{Sc}_{0.2} \mathrm{PO}_{4}$ are similar for the same Nd concentration. A Nd$\mathrm{P}$ distance variation of around $1 \%$ does not influence the relaxation mechanism but it is true that this variation is very small.

To analyze the variations shown in Figure 10, one could also have considered and compared $\mathrm{LaPO}_{4}$ with $\mathrm{Ba}_{5}\left(\mathrm{PO}_{4}\right)_{3} \mathrm{Cl}$ as their crystalline structure and their average Nd-P distance are different (average Nd-P distance in alforsite $=3.71 \AA$, considering that the Nd substitutes the $\mathrm{Ba}^{2+}$ ions). However, the constant value of $1 / T_{1}$ with the $\mathrm{Nd}$ concentration (in the $0-10^{-}$ ${ }^{4} \mathrm{~mol} / \mathrm{cm}^{3}$ range) tends to prove that the $\mathrm{Nd}^{3+}$ ions are not incorporated into the alforsite structure.

\subsubsection{Influence of the P-P distances}

In Eq. 4, $b_{2}$ is defined as the distance below the shift of the nuclear resonance frequency due to their dipolar coupling with the electronic magnetic moment makes the nuclear spin diffusion ineffective. A mathematical expression is given by Goudemond, ${ }^{38}$ and $b_{2}$ is only function of the P-P distance $d_{\mathrm{P}-\mathrm{P} \text {. As }} b_{2} \propto\left(d_{\mathrm{P}-\mathrm{P}}\right)^{1 / 4}, 1 / T_{1}$ can be written as:

$$
\frac{1}{T_{1}} \propto C \tau_{1} \frac{1}{\left(d_{\mathrm{P}-\mathrm{P}}\right)^{3 / 4}}
$$

The different values of $d_{\mathrm{P}-\mathrm{P}}$, calculated for $\mathrm{LaPO}_{4}$ and $\mathrm{YPO}_{4}$ crystals with $\mathrm{Vesta}^{24}$ when considering the $6 \mathrm{P}$ in the first coordination sphere, are reported in Table 3 for each compound. Figure 11 shows the variation of $1 / T_{1}$ as a function of $1 /\left(d_{\mathrm{P}-\mathrm{P}}\right)^{3 / 4}$ for fixed Nd concentrations: $C$ $=1.0^{*} 10^{-4}, 1.8^{*} 10^{-4}, 2.0^{*} 10^{-4}, 3.0^{*} 10^{-4}, 4.0^{*} 10^{-4}, 5.0^{*} 10^{-4}$ and $6.0^{*} 10^{-4} \mathrm{~mol} / \mathrm{cm}^{3}$. Those concentrations have been chosen arbitrarily in the $0-10^{-3} \mathrm{~mol} / \mathrm{cm}^{3}$ range, which is the range under consideration in this study. The values of $1 / T_{1}$ for each concentration and each compound 
are extracted from the fits obtained on Figure 10. The linear trend confirms that the ${ }^{31} \mathrm{P}$ relaxe through a fast spin diffusion regime and highlights the fact that, in such a regime, the P-P distance is a key parameter. The shortest the P-P distance, the faster the relaxation rate.

Table 3: Distances between $P$ and $P$ atoms in the different studied structures. These distances were obtained using Vesta software and JCPDF files 01-084-0335 for $\mathrm{YPO}_{4}$ and 01-083-0651 for $\mathrm{LaPO}_{4}$ and by Whetherall et al. for the glass. ${ }^{40}$

\begin{tabular}{|c|c|c|}
\hline Compounds & $\begin{array}{c}\text { Mean distances } d_{\mathrm{P}-\mathrm{P}}(\text { in } \AA) \\
\text { between phosphorus atoms }\end{array}$ & $\left(d_{\mathrm{P}-\mathrm{P})^{-3 / 4}\left(\text { in }^{-3 / 4}\right)}\right.$ \\
\hline $\mathrm{YPO}_{4}$ & 5.96 & 0.262 \\
\hline $\mathrm{LaPO}_{4}$ & 4.27 & 0.337 \\
\hline Glass & 2.95 & 0.444 \\
\hline
\end{tabular}

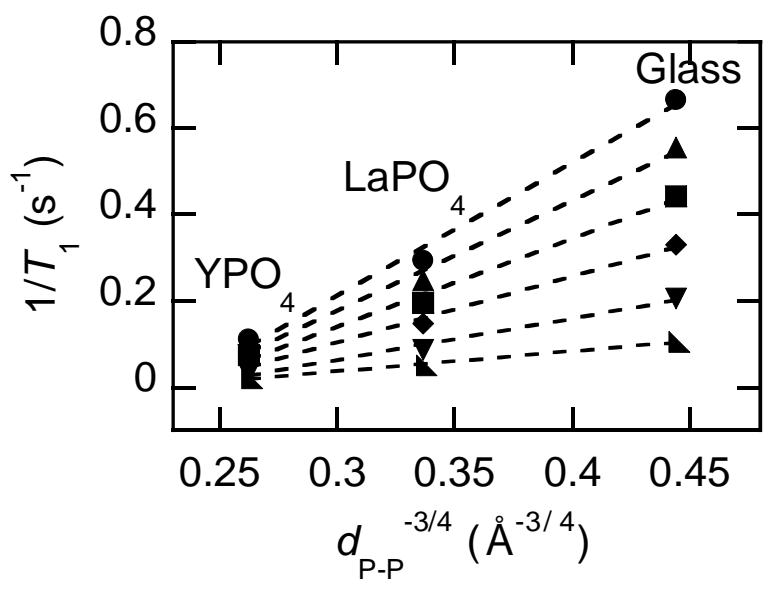

Figure 11: Values of $1 / T_{1}$ at a neodymium concentration of $6.0 * 10^{-4} \mathrm{~mol} / \mathrm{cm}^{3}($ circles$), 5.0 * 10^{-4} \mathrm{~mol} / \mathrm{cm}^{3}(\mathrm{top}$ triangles), $4.0^{*} 10^{-4} \mathrm{~mol} / \mathrm{cm}^{3}$ (squares), $3.0^{*} 10^{-4} \mathrm{~mol} / \mathrm{cm}^{3}$ (diamonds), $1.8 * 10^{-4} \mathrm{~mol} / \mathrm{cm}^{3}(\mathrm{bottom}$ triangles) and $1.0^{*} 10^{-4} \mathrm{~mol} / \mathrm{cm}^{3}$ (bottom left triangles)for our three different structures (monazite $\mathrm{LaPO}_{4}$, xenotime $\mathrm{YPO}_{4}$ and phosphate glass) in function of the average distance Phosphor - Phosphor $d_{\mathrm{P}-\mathrm{P}} \mathrm{P}^{-0.75}$. The different linear laws are respectively: $1 / T_{1}=\mathbf{- 0 . 7 1 1 8 4}+3.0759 d_{\mathrm{P}-\mathrm{P}^{-0.75},}, \quad 1 / T_{1}=-\mathbf{0 . 5 8 8 1 3}+\mathbf{2 . 5 5 1 7} d_{\mathrm{P}-\mathrm{P}}-0.75, \quad 1 / T_{1}=-$ $0.47090+2.0380 d d_{\mathrm{P}-\mathrm{P}^{-0.75},} 1 / T_{1}=-0.35197+1.5230 d d_{\mathrm{P}-\mathrm{P}^{-0.75}} 1 / T_{1}=-0.22355+0.95727 d \mathrm{P}_{\mathrm{P}} \mathrm{P}^{-0.75}$, and $1 / T_{1}=-$ $0.10499+0.44710 d$ P.P. ${ }^{-0.75}$, with $T_{1}$ in $\mathrm{s}$ and $d \mathrm{P}-\mathrm{P}$ in $\AA$.

\subsubsection{General description of the variation of $1 / T_{1}$}

Our different measurements show two main parameters involved in the nuclear relaxation of ${ }^{31} \mathrm{P}$ in the presence of $\mathrm{Nd}^{3+}$ ions in their vicinity:

(1) the molar concentration of $\mathrm{Nd}, C$, as shown on Figure 10;

(2) the P-P distances, expressed by the law: 


$$
\frac{1}{T_{1}}=\frac{\alpha}{\left(d_{\mathrm{P}-\mathrm{P}}\right)^{3 / 4}}+\beta
$$

established for a given $\mathrm{Nd}$ concentration (Figure 11).

With the aim of determining a universal law allowing the calculation of $T_{1}$ for an unknown material and $\mathrm{Nd}$ concentration, these two laws can be gathered and we thus propose to consider the variation of $1 / T_{1}$ as:

$$
\frac{1}{T_{1}}=\frac{\delta C}{\left(d_{\mathrm{P}-\mathrm{P}}\right)^{3 / 4}}+\varepsilon C
$$

where $\delta$ and $\varepsilon$ are two parameters that can be determined using the fits obtained on Figure 11 for the different concentrations.

Figure 12 displays the variation of $1 / T_{1} \mathrm{C}$ as a function of the corresponding $d_{\mathrm{P}-\mathrm{P}}{ }^{-3 / 4}$ for six different concentrations and for three of our compounds.

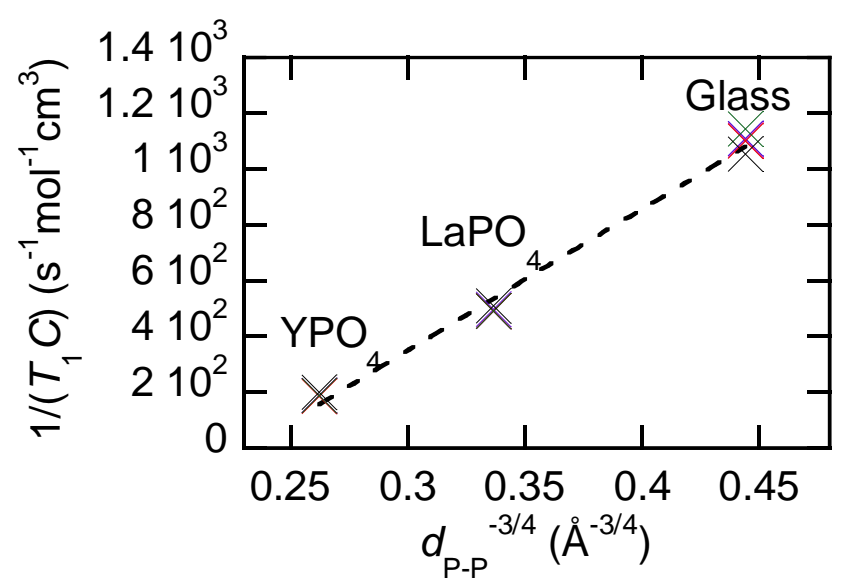

Figure 12: Values of $1 / T_{1}$ at a neodymium concentration $C$ of $6.0 * 10^{-4}$ (blue), $5.0 * 10^{-4}$ (purple), $4.0 * 10^{-4}$ (pink), 3.0*10 $0^{-4}\left(\right.$ red), $1.8 * 10^{-4}$ (green) and $1.0 * 10^{-4} \mathrm{~mol} / \mathrm{cm}^{3}$ (black) for our three different structures (monazite $\mathrm{LaPO}_{4}$, xenotime $\mathrm{YPO}_{4}$ and phosphate glass) in function of the average distance Phosphor Phosphor $d \mathrm{P} \cdot \mathrm{P}^{-0.75}$. The linear law is: $1 /\left(T_{1} C\right)=-1173.2+5076.7 d \mathrm{P}-\mathrm{P}^{-3 / 4}$, with $T_{1}$ in $\mathrm{s}, C$ in $\mathrm{mol} / \mathrm{cm}^{3}$ and $d \mathrm{P}-\mathrm{P}$ in Å.

We find a remarkable linear dependence for our three compounds of interest, with characteristic P-P distances that are quite different, and although they exhibit a very different structure when comparing crystals and glass. This clearly shows that the two parameters $\delta$ and $\varepsilon$ do not depend on the material and are thus intrinsic to the dopant element (Neodymium here) and to the Phosphor atom and their respective interactions independently from their arrangement at the microscopic scale. 
Hence, a result of this study is to propose an empiric law that links three different parameters of $\mathrm{Nd}^{3+}$ doped phosphates: the concentration $C$ (in $\mathrm{mol} / \mathrm{cm}^{3}$ ) of paramagnetic ions, the nuclear relaxation time $T_{1}$ (in s) and the Phosphor-Phosphor distance $d_{\mathrm{P}-\mathrm{P}}$, in $\AA$, characteristic of each material:

$$
\frac{1}{T_{1} C}=\frac{5077}{\left(d_{\mathrm{P}-\mathrm{P}}\right)^{3 / 4}}-1173
$$

\section{Conclusion}

In this study different ${ }^{31} \mathrm{P}$-based compounds were considered in order to evaluate the possibility to measure low paramagnetic $\mathrm{Nd}^{3+}$ doping concentration using a technique based on solid-state NMR relaxation. We show that the relaxation rate $1 / T_{1}$ varies linearly with the $\mathrm{Nd}^{3+}$ concentration for a given compound and that, for a given $\mathrm{Nd}$ concentration, it varies linearly with $1 / \mathrm{d}_{\mathrm{P}-\mathrm{P}} 3 / 4$, where $d_{\mathrm{P}-\mathrm{P}}$ is the average distance between ${ }^{31} \mathrm{P}$ closest neighbors. By considering these two variations, we further derived a simple empiric law describing the variation of $1 / T_{1}$ as a function of $C$ and $d_{\text {P-P. }}$. It would now be interesting to check for the validity of this law for any other phosphate compounds expecting to show some universal behavior, and to get a theoretical description of the physical phenomena driving the values of the two fitted constant $\delta$ and $\varepsilon$. Moreover, this kind of approach could probably be extended to any other material hosting paramagnetic ions inside an NMR sensitive matrix (fluorides, silicates...).

\section{Acknowledgements}

The authors would like to thank François Devreux and Vera Pukhkaya for their help. 
1. Rare-Earth Doped III- Nitrides for Optoelectronic and Spintronic Applications, Springer Netherlands, Dordrecht, 2010.

2. F. Beaudoux, R. Marino, J. Lejay, A. Ferrier, B. Tumino, O. Guillot-Noel and P. Goldner, Journal of Luminescence, 2011, 131, 469-472.

3. F. Benz, A. Gonser, R. Volker, T. Walther, J. T. Mosebach, B. Schwanda, N. Mayer, G. Richter and H. P. Strunk, Journal of Luminescence, 2014, 145, 855-858.

4. G. Blasse and B. C. Grabmaier, Luminescent Materials Springer Berlin Heidelberg, 1994.

5. A. Lyberis, A. J. Stevenson, A. Suganuma, S. Ricaud, F. Druon, F. Herbst, D. Vivien, P. Gredin and M. Mortier, Optical Materials, 2012, 34, 965-968.

6. C. Houtong, L. Rui, Y. Min, L. Liren, Z. Weiping, X. Shangda and K. Jean-Claude, Journal of Physics: Condensed Matter, 2001, 13, 1151.

7. E. Cantelar, J. A. Sanz-Garcia and F. Cusso, Journal of Crystal Growth, 1999, 205, 196201.

8. S. Rodriguez-Liviano, F. J. Aparicio, T. C. Rojas, A. B. Hungria, L. E. Chinchilla and M. Ocana, Crystal Growth \& Design, 2012, 12, 635-645.

9. M. Castellanos and A. R. West, Journal of the Chemical Society-Faraday Transactions I, 1980, 76, 2159-2169.

10. A. Abragam and B. Bleaney, Electron Paramagnetic Resonance of Transitions Ions, Clarendon Press, London, 1970.

11. O. Guillot-Noël, P. Goldner, P. Higel and D. Gourier, Journal of Physics-Condensed Matter, 2004, 16, R1-R24.

12. G. Dantelle, M. Mortier, P. Goldner and D. Vivien, Journal of Physics-Condensed Matter, 2006, 18, 7905-7922.

13. S. Maron, G. Dantelle, T. Gacoin and F. Devreux, Physical Chemistry Chemical Physics, 2014, 16, 18788-18798.

14. E. M. Levin, J. P. Heremans, M. G. Kanatzidis and K. Schmidt-Rohr, Physical Review $B, 2013, \mathbf{8 8}, 115211$.

15. S. Sen and J. F. Stebbins, Physical Review B, 1994, 50, 822-830.

16. W. Y. Li, V. R. Celinski, J. Weber, N. Kunkel, H. Kohlmann and J. S. auf der Gunne, Physical Chemistry Chemical Physics, 2016, 18, 9752-9757.

17. J. Cui, E. M. Levin, Y. Lee and Y. Furukawa, Physical Review B, 2016, 94, 085203.

18. R. O. Omrani, A. Kaoutar, A. El Jazouli, S. Krimi, I. Khattech, M. Jemal, J. J. Videau and M. Couzi, Journal of Alloys and Compounds, 2015, 632, 766-771.

19. D. Brégiroux, F. Audubert, T. Charpentier, D. Sakellariou and D. Bernache-Assollant, Solid State Sciences, 2007, 9, 432-439.

20. G. Ju, Y. Hu, L. Chen and X. Wang, Journal of Applied Physics, 2012, 111, 113508.

21. V. Pukhkaya, F. Trompier and N. Ollier, Journal of Applied Physics, 2014, 116, 123517.

22. J. Rodríguez-Carvajal, Physica B: Condensed Matter, 1993, 192, 55-69.

23. J. Rodríguez-Carvajal, Commission on Powder Diffraction, 2001, 26, 12.

24. K. Momma and F. Izumi, Journal of Applied Crystallography, 2011, 44, 1272-1276.

25. Y. Ni, J. M. Hughes and A. N. Mariano, American Mineralogist, 1995, 80, 21-26.

26. A. C. Palke and J. F. Stebbins, American Mineralogist, 2011, 96, 1343-1353.

27. A. C. Palke, J. F. Stebbins and L. A. Boatner, Inorganic Chemistry, 2013, 52, 1260512615.

28. R. J. McCarty and J. F. Stebbins, Solid State Nuclear Magnetic Resonance, 2016, 79, 11-22.

29. V. Buissette, A. Huignard, T. Gacoin, J.-P. Boilot, P. Aschehoug and B. Viana, Surface Science, 2003, 532-535, 444-449. 
30. S. Briche, D. Zambon, G. Chadeyron, D. Boyer, M. Dubois and R. Mahiou, Journal of Sol-Gel Science and Technology, 2010, 55, 41-51.

31. N. C. George, A. J. Pell, G. Dantelle, K. Page, A. Llobet, M. Balasubramanian, G. Pintacuda, B. F. Chmelka and R. Seshadri, Chemistry of Materials, 2013, 25, 39793995.

32. D. Massiot, F. Fayon, M. Capron, I. King, S. Le Calvé, B. Alonso, J.-O. Durand, B. Bujoli, Z. Gan and G. Hoatson, Magnetic Resonance in Chemistry, 2002, 40, 70-76.

33. M. Braun, P. Hartmann and C. Jana, J Mater Sci: Mater Med, 1995, 6, 150-154.

34. S. H. Santagneli, J. J. Ren, M. T. Rinke, S. J. L. Ribeiro, Y. Messaddeq and H. Eckert, Journal of Non-Crystalline Solids, 2012, 358, 985-992.

35. K. Zou, H. Guo, M. Lu, W. Li, C. Hou, W. Wei, J. He, B. Peng and B. Xiangli, Opt. Express, 2009, 17, 10001-10009.

36. S. Sen and J. F. Stebbins, Journal of Non-Crystalline Solids, 1995, 188, 54-62.

37. A. Abragam, The Principles of Nuclear Magnetism, Clarendon Press, London, 1961.

38. I. P. Goudemond, J. M. Keartland, M. J. R. Hoch and G. A. Saunders, Physical Review $B, 2001,63,054413$.

39. J. Laugier and B. Bochu, LMGP-Suite Suite of Programs for the interpretation of X-ray Experiments, http://www.inpg.fr/LMGP and http://www.ccp14.ac.uk/tutorial/lmgp.

40. K. M. Wetherall, D. M. Pickup, R. J. Newport and G. Mountjoy, Journal of Physics: Condensed Matter, 2009, 21, 035109. 